\title{
Therapeutic Management of Cystic Calculi Induced Cystitis in a Dog
}

\author{
E. Venkatesakumar ${ }^{\text {* }}$, P.A. Enbavelan ${ }^{1}$, K. Jeyaraja ${ }^{2}$, V. Kumar' ${ }^{1}$ and R. Ramprabhu ${ }^{3}$ \\ ${ }^{1}$ Department of Veterinary Medicine, VCRI, Tirunelveli, Tamil Nadu, India \\ ${ }^{2}$ Department of Veterinary Clinical Medicine, MVC, Chennai, Tamil Nadu, India \\ ${ }^{3}$ TVCC, VCRI, Tirunelveli, Tamil Nadu, India \\ *Corresponding author
}

\section{A B S T R A C T}

\begin{tabular}{|l|}
\hline K e y w o r d s \\
$\begin{array}{l}\text { Dalmatian, Suppurative } \\
\text { cystitis, Urate crystals, } \\
\text { Struvite crystals, } \\
\text { Urohydropropulsion }\end{array}$ \\
\hline Article Info \\
\hline $\begin{array}{l}\text { Accepted: } \\
\text { 15 July } 2018 \\
\text { Available Online: } \\
10 \text { August } 2018\end{array}$ \\
\hline
\end{tabular}

\section{Introduction}

The cystitis in dogs is mainly due to inflammation and bacterial infections of urinary bladder either bacteria migrating up from the lower urinary tract or secondary to calculi knocking around in the urinary bladder, withholding the urine for longtime, or infections in prostate, kidney, uterus, etc. Dalmatian breed of dog is more likely to be affected with urate calculi due to inherited defect in uric acid metabolism like impaired transport of urate across hepatocyte cell membrane (Giesecke and Tiemeyer, 1984), delayed intestinal uptake of urate and hypoxanthine (Briggs and Harley, 1986) and reduced renal absorption of urate (Roch-
Ramel et al., 1976). In the present case, both urate and struvite calculi with suppurative cystitis in a Dalmatian dog was documented.

\section{Case history and observations}

A six year old male Dalmatian dog was presented to small animal medicine outpatient unit of Teaching Veterinary Clinical Complex, Veterinary College and Research Institute, Tirunelveli with the history of not voiding urine, anorexia and gradual distention of abdomen for the past 3 days. Elevated body temperature $\left(39.8^{\circ} \mathrm{C}\right)$, congested mucus membrane, moderate dehydration, distended and tense urinary bladder on palpation of abdomen were recorded in general clinical 
examination. Haematobiochemical examination revealed moderate anaemia $(\mathrm{Hb}-$ $8.0 \mathrm{~g} / \mathrm{dl}, \quad$ PCV - $26.4 \%, \quad \mathrm{RBC}-4.52$ $\mathrm{x} 10^{6} /$ cumm) leukocytosis $(24,600 /$ cumm) with neutrophilia $(78 \%)$, elevated blood urea nitrogen $(103.5 \mathrm{mg} / \mathrm{dl})$ and serum creatinine $(4.1 \mathrm{mg} / \mathrm{dl})$. Radiography showed distended urinary bladder with numerous cystoliths. Ultrasonography of the abdomen revealed distended urinary bladder with hyperechoic sediments and cystolith (plate 1). Cystocentesis was performed to relieve the pressure in the urinary bladder and to collect urine sample for cultural examination. After performing retrograde urohydropropulsion, urinary catheter was passed and remaining urine was collected from urinary bladder. Total volume of $350 \mathrm{ml}$ of yellowish cloudy urine was collected (plate 2). Urinalysis revealed slightly alkaline urine $(\mathrm{pH}$ 7.4), presence of numerous urate and struvite crystals (plate 3), granular casts, leukocytes, erythrocytes and bacterial rods and cocci. Cultural examination of urine showed Staphylococcus spp. and Escherichia coli and sensitivity to enrofloxacin and amoxicillin + clavulanic acid. Based on the history, clinical findings and laboratory findings, the case was diagnosed as suppurative cystitis.

\section{Treatment and Discussion}

The animal was treated with Inj. Dextrose normal saline @ $10 \mathrm{ml} / \mathrm{kg}$ iv and Inj. Ringer's lactate @ $10 \mathrm{ml} / \mathrm{kg}$ iv for five days along with Tab. Enrofloxacin @ $5 \mathrm{mg} / \mathrm{kg}$ bwt sid po, Tab. Allopurinol @ $10 \mathrm{mg} / \mathrm{kg}$ bwt tid po and oral haematinics 15 days. Urolithiasis induced cystitis is common in dogs. Crystal solubility is mainly depending upon urine $\mathrm{pH}$. Struvite urolith is most common uroliths of dogs formed in alkaline urine found in urinary tract infection due to urease producing bacteria like Staphylococcus and Proteus, calcium phosphate in alkaline to neutral urine, calcium oxalate and silica in neutral to acidic urine and urate, xanthine and cystine in acidic urine (Adams and Syme, 2005). Urate crystals may also occur due to liver disorders and portosystemic shunts in dogs. In the present case, the Dalmatian dog was having normal liver function precluded the liver disorder in the formation of urate crystals. It might be due to enzyme defect specific for Dalmatian dog. The mechanical damage of urinary bladder by the urate calculi might predispose for cystitis or urinary tract infections with urease producing bacteria like Staphylococcus, Proteus and E. coli might have increased ammonium ions which predisposed to ammonium urate calculi formation. Seguin $e t$ al., (2003) reported that Escherichia coli, Proteus spp, Staphylococcus spp. were the major pathogens in the canine urinary tract infections.

In the present case, Staphylococcus and Escherichia coli were isolated in the urine culture. Staphylococcus contains urease and is capable of splitting urea into ammonia and carbon dioxide. Hydroxyl and ammonium ions are formed by the hydrolysis of ammonia, which decreases hydrogen ion concentrations in urine, resulting in an alkaline urine $\mathrm{pH}$ and decreased struvite solubility. The calcium oxalate and struvite are largely radiopaque and urate, cystine and calcium phosphate are variably radiopaque. Hence, for accurate diagnosis of the urolithiasis in dogs, combination of ultrasonography and survey radiography is needed (Kyles et al., 2005). Urine sediment examination and urine culture are useful in identifying the type of calculi, pyuria or bacteriuria and identification of bacteria (Gatoria et al., 2006). Bacterial urine culture and sensitivity testing are important in all animals with urolithiasis to identify and properly select the antibiotics in concurrent urinary tract infections (Olin and Bartges, 2015). In the present case, enrofloxacin was administered based upon urine culture and sensitivity test. 
Plate.1 Ultrasound examination of urinary bladder showed hyperechoic sediments and cystoliths

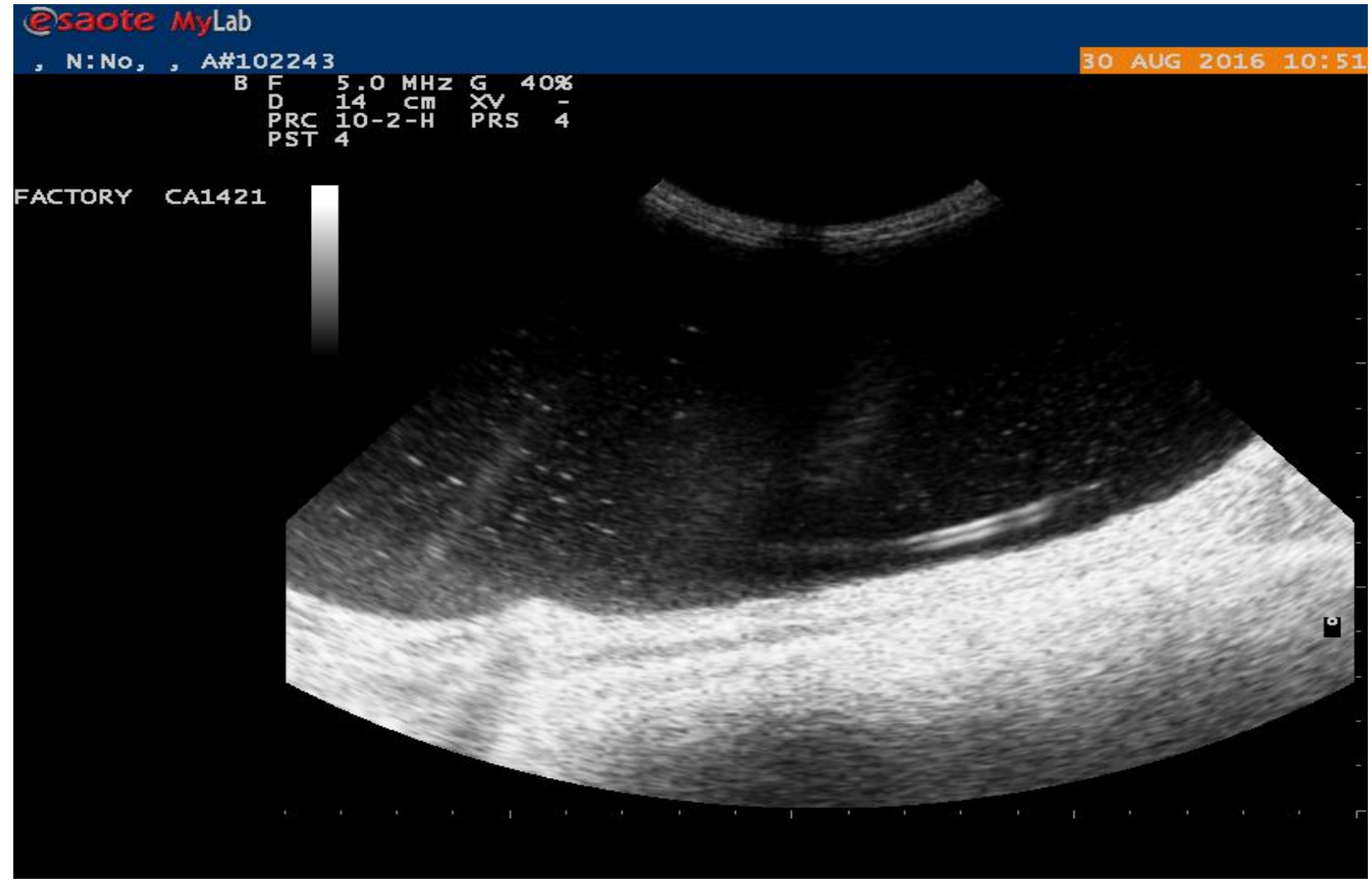

Plate.2 Yellowish cloudy urine

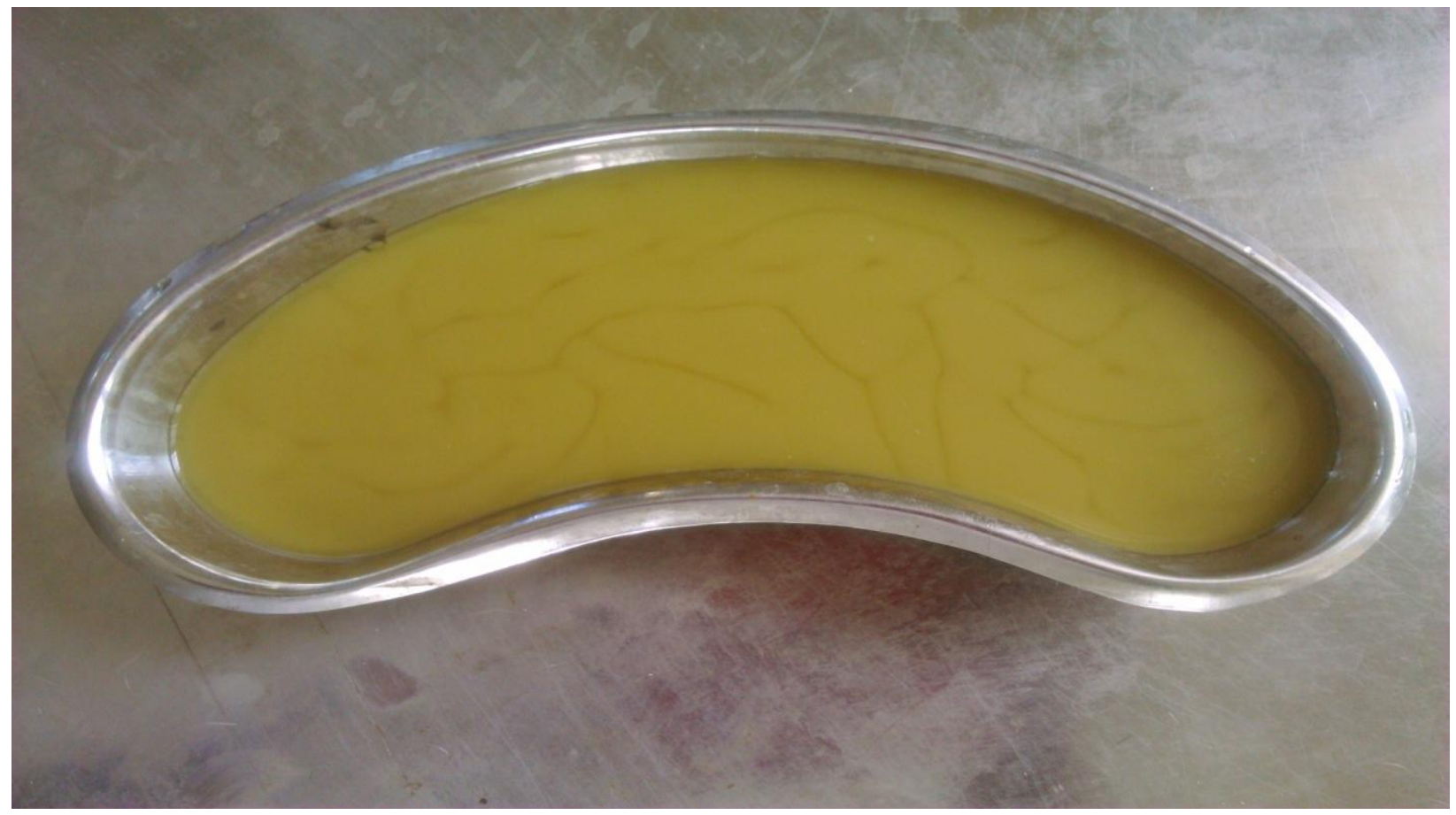


Plate.3 Urine sediment examination showed urate and struvite crystals

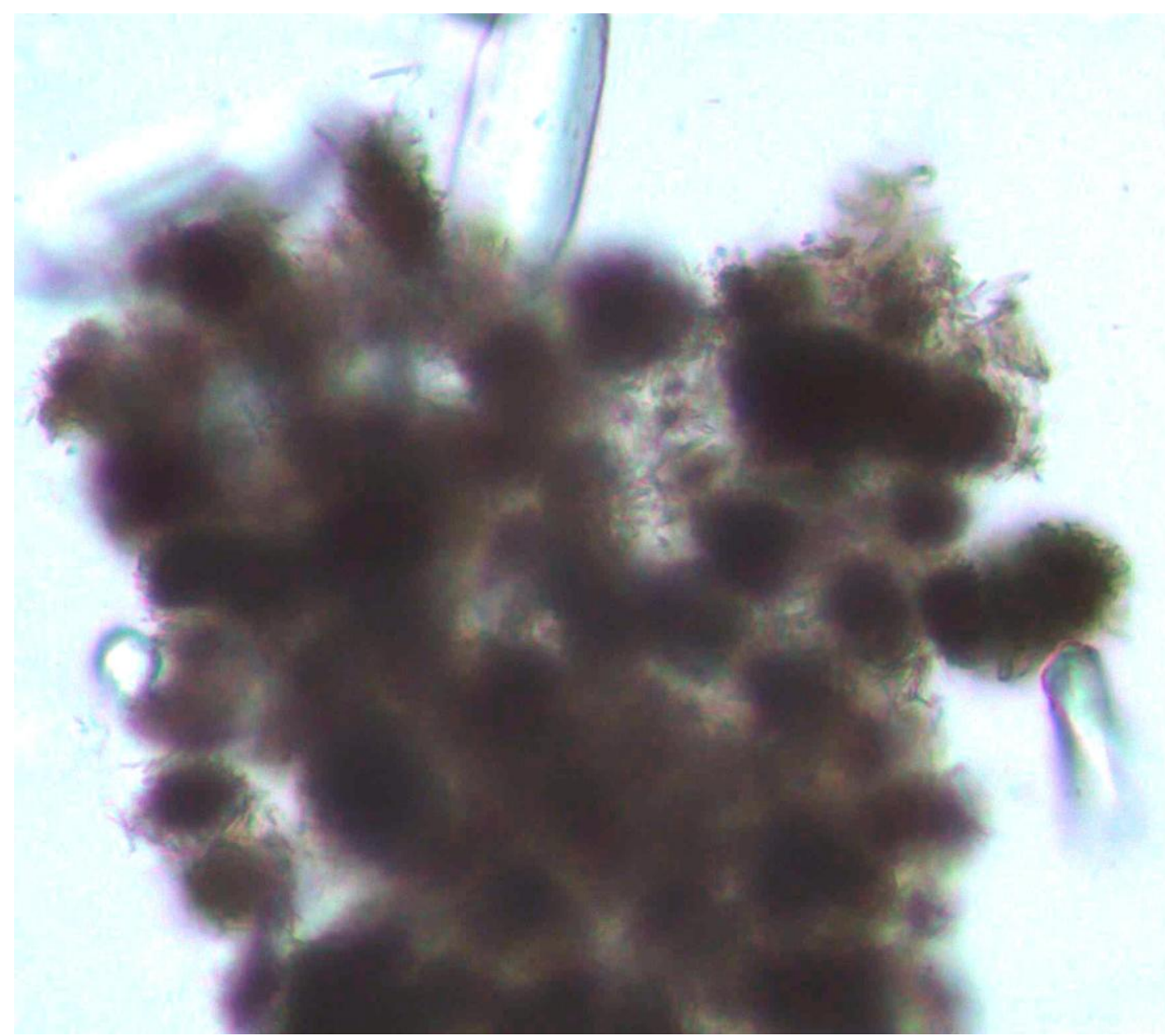

The long course of 7 to 14 days treatment was needed for the management of complicated case of cystitis in dogs. Enrofloxacin, Amoxicillin + clavulanic acid and Sulfamethoxazole + trimethoprim were having good activity against canine urinary tract infections (Weese et al., 2011). Allopurinol is a competitive inhibitor of the enzyme xanthine oxidase, so it can be administered in dogs for the management of urate crystals in Dalmatian dogs (Bartges et al., 1999). In the present study, there was post renal azotemia and it was managed by fluid therapy. Post treatment haematology and serum biochemistry were within normal. The dog had the normal urine flow. Post treatment urine sediment and cultural examination showed normal $\mathrm{pH}$ and absence of crystals and bacteria. For the prevention of Struvite urolith, the commercially available diet with lower urinary phosphate and magnesium is to be fed and also to maintain an acidic urine by elimination of urease-producing bacterial infections. The low protein and purine diet and alkalinization of urine are to be followed for the prevention of urate uroliths.

\section{Summary}

Urate and struvite caliculi induced suppurative cystitis in Dalmatian dog was diagnosed by clinical signs, haematobiochemical examination, radiography and ultrasonography. The animal was treated successfully by the administration of enrofloxacin, allopurinol and fluid therapy. 


\section{Acknowledgment}

The authors are thankful to the Dean, Veterinary College and Research Institute, Tirunelveli for the facilities provided.

\section{References}

Adams, L. G. and Syme, H. M. 2005. Canine lower urinary tract diseases. In: Textbook of Veterinary Internal Medicine. Vol. 2. $6^{\text {th }}$ edn, eds S. J. Ettinger \& E. C. Feldman, Elsevier Saunders, St. Louis, pp. 1850- 1874.

Bartges, J.W., Osborne. C. A, Lulich. J. P, Kruger. J. M, Sanderson. S. L, Koehler. L. A. and Ulrich. L.K. 1999. Canine urate urolithiasis. Etiopathogenesis, diagnosis, and management. Vet Clin North Am Small Anim Pract. 29(1):161-91.

Briggs, D. M. and Harley. E. H. 1986. The fate of administered purines in the Dalmatian coach hound. Journal of Comparative Pathology, 96: 267-278.

Gatoria, I. S., Saini. N. S, Rai. T. S. and Dwivein. P. N. 2006. Comparison of three techniques for the diagnosis of urinary tract infections in dogs with urolithiasis. Journal of Small Animal Practice, 47: 727-732.

Giesecke, D. and Tiemeyer W. 1984. Defect of uric acid uptake in Dalmatian dog liver. Experientia, 40: 1415-1416.

Kyles, A. E., Hardie. E. M, Wooden. B. G, Adin. C. A, Stone. E. A, Gregory. C. R,
Mathews. K. G, Cowgil. L. D. and Vaden. S. 2005. Clinical, clinicopathologic, radiographic, and ultrasonographic abnormalities in cats with ureteral calculi: 163 cases (19842002). Journal of the American Veterinary Medical Association, 226: 932-936.

Olin, S. J. and Bartges. J. W. 2015. Urinary tract infections: treatments/comparative therapeutics, Vet Clin North Am Small Anim Pract. 45(4): 721-746.

Roch-Ramel, F., Wong. N. L. M. and Dirks. J. H. 1976. Renal excretion of urate in mongrel and Dalmatian dogs: A micropuncture study. American Journal of Physiology, 231: 326-331.

Seguin, M.A., Vaden. S. L, Altier. C, Stone. E. and Levine. J. F. 2003. Persistent urinary tract infections and reinfections in 100 dogs (1989-1999) J Vet Intern Med. 17(5):622-631.

Weese, J. S., Blondeau. J. M, Boothe. D, Breitschwerdt. E. B, Guardabassi. L, Hillier. A, Lloyd. D. H, Papich. M. G, Rankin. S. C, Turnidge. J. D. and Sykes. J. E. 2011. Antimicrobial use guidelines for treatment of urinary tract disease in dogs and cats: antimicrobial guidelines working group of the International Society for Companion Animal Infectious Diseases, Vet Med Int, DOI: $10.4061 / 2011 / 263768$.

\section{How to cite this article:}

Venkatesakumar, E., P.A. Enbavelan, K. Jeyaraja, V. Kumar and Ramprabhu, R. 2018. Therapeutic Management of Cystic Calculi Induced Cystitis in a Dog. Int.J.Curr.Microbiol.App.Sci. 7(08): 2507-2511. doi: https://doi.org/10.20546/ijcmas.2018.708.254 